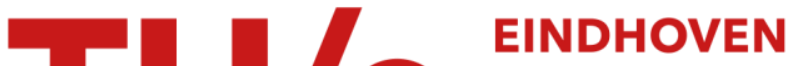 UNIVERSITY OF TECHNOLOGY
}

\section{A comprehensive model of a fluidized bed membrane reactor for small-scale hydrogen production}

\section{Citation for published version (APA):}

Foresti, S., Di Marcoberardino, G., Manzolini, G., De Nooijer, N., Gallucci, F., \& van Sint Annaland, M. (2018). A comprehensive model of a fluidized bed membrane reactor for small-scale hydrogen production. Chemical Engineering and Processing : Process Intensification, 127, 136-144. https://doi.org/10.1016/j.cep.2018.01.018

\section{Document license: \\ TAVERNE}

DOI:

10.1016/j.cep.2018.01.018

\section{Document status and date:}

Published: 01/05/2018

\section{Document Version:}

Publisher's PDF, also known as Version of Record (includes final page, issue and volume numbers)

\section{Please check the document version of this publication:}

- A submitted manuscript is the version of the article upon submission and before peer-review. There can be important differences between the submitted version and the official published version of record. People interested in the research are advised to contact the author for the final version of the publication, or visit the $\mathrm{DOI}$ to the publisher's website.

- The final author version and the galley proof are versions of the publication after peer review.

- The final published version features the final layout of the paper including the volume, issue and page numbers.

Link to publication

\section{General rights}

Copyright and moral rights for the publications made accessible in the public portal are retained by the authors and/or other copyright owners and it is a condition of accessing publications that users recognise and abide by the legal requirements associated with these rights.

- Users may download and print one copy of any publication from the public portal for the purpose of private study or research.

- You may not further distribute the material or use it for any profit-making activity or commercial gain

- You may freely distribute the URL identifying the publication in the public portal.

If the publication is distributed under the terms of Article 25fa of the Dutch Copyright Act, indicated by the "Taverne" license above, please follow below link for the End User Agreement:

www.tue.nl/taverne

Take down policy

If you believe that this document breaches copyright please contact us at:

openaccess@tue.nl

providing details and we will investigate your claim. 


\title{
A comprehensive model of a fluidized bed membrane reactor for small-scale hydrogen production
}

\author{
S. Foresti ${ }^{\mathrm{a}, *}$, G. Di Marcoberardino ${ }^{\mathrm{a}}$, G. Manzolini ${ }^{\mathrm{a}}$, N. De Nooijer ${ }^{\mathrm{b}}$, F. Gallucci $^{\mathrm{b}}$, \\ M. van Sint Annaland ${ }^{\mathrm{b}}$ \\ a Politecnico di Milano, Department of Energy, via Lambruschini 4, 20156, Milano, Italy \\ ${ }^{\mathrm{b}}$ Eindhoven University of Technology, Department of Chemical Engineering and Chemistry, Chemical Process Intensification, De Rondom 70, 5612 AZ, Eindhoven, The \\ Netherlands
}

\section{A R T I C L E IN F O}

\section{Keywords:}

Fluidized bed membrane reactor

Hydrogen production

Autothermal reforming

Vacuum

Sweep gas

\begin{abstract}
A B S T R A C T
Membrane reactors, combining production and separation of pure hydrogen in one vessel, outperform conventional fuel processors for small-scale hydrogen production. Among different membrane reactor concepts, the fluidized bed membrane reactor shows advantages in terms of optimal gas-catalyst contact, heat management and reduced bed-to-membrane mass transfer limitations; the drawbacks are the limits of the fluidization regimes which set minimum and maximum feed flowrates. In this work, a comprehensive model of a fluidized bed membrane reactor is developed. The reactor produces hydrogen (around $3 \mathrm{Nm}^{3} / \mathrm{h}$ ) for the $5 \mathrm{~kW}_{\mathrm{el}}$-class PEMFCbased m-CHP systems using natural gas or bio-ethanol as feedstocks. Two different permeate options have been analyzed, namely vacuum and sweep gas configurations, together with detailed fluid-dynamics at the feed side. For the vacuum case the hydrogen output simulated with an ideal approach, i.e. without bubble-emulsion phase distinction, kinetic and mass transfer limitations, is overestimated by $10 \%$ with respect to the full detailed model. In the sweep gas configuration the detailed models haves the hydrogen produced by the ideal model. The gas diffusion through the thick porous support of the membranes is the most limiting phenomena, and the reactor size and operation conditions must be selected carefully considering this to reach the desired output.
\end{abstract}

\section{Introduction}

Membrane reactors can increase the hydrogen production efficiency at small-medium scale thanks to their scalability. Examples of membrane reactor applications are the Tokyo Gas hydrogen production unit [1] as well as the prototypes developed within recent EU projects like Ferret [2], Fluidcell [3] and Bionico [4]. Natural gas is the most common feedstock adopted in membrane reactors [5-9], but other fuels such as ethanol or LPG [10-14] are also investigated. The membrane is typically made of Palladium or a Palladium alloys, because they guarantee the best compromise between permeance, selectivity and chemical stability [15]. The reaction occurs in a catalyst bed which can be either fixed or fluidized depending on the gas velocity. Fluidized bed operation is preferred because in fixed beds the hydrogen extraction along the membrane brings about heat management problems $[16,17]$ and reduces the hydrogen diffusion in the radial direction of the bed.

At low superficial velocity $\left(\mathrm{u}_{0}\right)$, the gas passes through the bed as through a porous media (fixed bed), with pressure drops increasing with the velocity. Increasing the gas velocity above a certain value, known as the minimum fluidization velocity $\left(\mathrm{u}_{\mathrm{mf}}\right)$, the bed reaches the minimum fluidization regime and expands in height. At higher gas velocities, the bed is characterized by large instabilities, with bubbles and vigorous mixing of the solids, called bubbling regime. The type of regime which occurs in the reactor is very important because the membrane reactor performance strongly depends on the hydrogen concentration along the membrane length as well as at the membranebed interface. Therefore, a detailed model of the bed fluidization is necessary to correctly design the membrane reactor.

The fluidization regime is usually characterized by the ratio of the superficial velocity by the minimum fluidization velocity $\left(\mathrm{u}_{0} / \mathrm{u}_{\mathrm{mf}}\right)$. Typically, in the range $\mathrm{u}_{0} / \mathrm{u}_{\mathrm{mf}}<10$ the bubbling regime prevails, and to avoid or limit solids entrainment it is necessary to compute the free terminal velocity of the particles $\left(u_{t}\right.$, above which the lift force of the gas prevails on the gravity force) and limit $\mathrm{u}_{\mathrm{t}} / \mathrm{u}_{\mathrm{mf}}<100$ for small particles, or $\mathrm{u}_{\mathrm{t}} / \mathrm{u}_{\mathrm{mf}}<10$ for larger particles [18].

Models of fluidized bed membrane reactors are present in literature, with different levels of detail. The simplest model of a membrane reactor, e.g. simulated in Aspen Plus using the standard components of

\footnotetext{
* Corresponding author.

E-mail address: stefano.foresti@polimi.it (S. Foresti).
} 


$\begin{array}{ll}\text { Nomenclature } \\ \\ \\ \text { A } & \text { Area } \\ \text { ATR } & \text { Auto-thermal reforming } \\ \mathrm{C} & \text { Molar concentration } \\ \mathrm{c}, \mathrm{c}_{\mathrm{p}}, \mathrm{c}_{\mathrm{v}} & \text { Heat capacity } \\ \mathrm{CSTR} & \text { Continuous stirred tank reactor } \\ \mathrm{D} & \text { Diameter } \\ \mathrm{d}_{\mathrm{b}} & \text { Diameter (bubble) } \\ \mathrm{D}_{\mathrm{ij}} & \text { Diffusivity } \\ \mathrm{E}_{\mathrm{a}} & \text { Activation energy } \\ \mathrm{F} & \text { Molar flow rate } \\ \mathrm{g} & \text { Gravity acceleration } \\ \mathrm{h} & \text { Specific enthalpy } \\ \mathrm{HRF} & \text { Hydrogen recovery factor } \\ \mathrm{J} & \text { Molar flux } \\ \mathrm{K} & \text { Mass transfer coefficient } \\ \mathrm{k}_{\mathrm{O}} & \text { Permeabilty } \\ \mathrm{k} & \text { Permeance } \\ \mathrm{m} & \text { Mass } \\ \mathrm{m}-\mathrm{CHP} & \text { Micro-combined heat and power } \\ \mathrm{MR} & \text { Membrane reactor } \\ \mathrm{MW} & \text { Molecular weight } \\ \mathrm{P} & \text { Pressure } \\ \mathrm{PEMFC} & \text { Polymeric electrolyte membrane fuel cell } \\ \mathrm{PFR} & \text { Plug flow reactor } \\ \end{array}$

\section{Radius}

Reaction rate

Universal gas constant

Steam reforming

Temperature

Velocity

Superficial gas velocity

$\begin{array}{ll}\mathrm{u}_{\mathrm{br}} & \text { Bubbles relative velocity } \\ \mathrm{u}_{\mathrm{t}} & \text { Terminal velocity of solid }\end{array}$

$\mathrm{V} \quad$ Volume

WGS Water gas shift

$\mathrm{x}_{\mathrm{i}} \quad$ Molar fraction

$\delta \quad$ Thickness

$\delta_{\mathrm{b}} \quad$ Fraction (bubble)

$\varepsilon \quad$ Support porosity; emulsion void fraction

$\mu \quad$ Viscosity

$\tau \quad$ Tortuosity

\section{Subscripts}

$\begin{array}{ll}\mathrm{b} & \text { Bubble } \\ \mathrm{e} & \text { Emulsion } \\ \mathrm{i} & \text { Chemical species } \\ \mathrm{mf} & \text { Minimum fluidization } \\ \text { per } & \text { Permeate } \\ \text { ret } & \text { Retentate } \\ \mathrm{s} & \text { Solid particles }\end{array}$

this software, is based on a sequence of reactors at chemical equilibrium and separators to emulate the effects of the membranes, but totally neglecting the gas distribution between emulsion and bubble phases. It has been used for preliminary analysis of more complex systems, like mCHP units based on membrane reactor and PEM fuel cells [7,14,19,20] with natural gas or bio-ethanol feedstock, vacuum or sweep gas on the permeate side. A comparison of such simple models with a more detailed one accounting for bubble and emulsion phases and reaction kinetics, has revealed that, for a given hydrogen output, the simple models underestimate the membrane area by $20-30 \%$ when using natural gas auto-thermal reforming with vacuum conditions at the permeate side [8], suggesting the importance of developing more detailed models. Most of the works are based on the so called "simple twophase" model, i.e. considering the emulsion phase in minimum fluidization conditions and the catalyst-free bubble phase through which the excess gas flows. The most common approach is to create parallel sequences of different interconnected reactors for the emulsion phase and the bubble phase: a series of continuous stirred tank reactors (CSTRs) for the emulsion phase and plug flow reactors (PFRs) for the bubble phase [8,21-24]. In fact, while the bubbles flow approximately straight upward along the reactor, the vigorous solid mixing in the emulsion (e.g. due to macro-scale solids circulation and transport of species adsorbed in the solid pores) enhances the gas back-mixing and moves away from the ideal plug flow behavior. Among these "sequential models", Ref. [21-23] adopt membranes starting from the bottom of the reactor with sweep gas in co-flow direction with the feed and highlight the importance of modeling the free-board region also in bubbling beds; Ref. [8,24] use suspended membranes, which creates a discontinuity in the evolution of the bubbles rising from the bottom, and sub-atmospheric pressure without sweep gas on the permeate side.

In the case of high-permeability membranes which remove significant amounts of hydrogen from the fluidized bed, local de-fluidized zones may occur close to the membrane surface, thus increasing the bed-to-membrane mass transfer resistance and partially erasing the benefits of the fluidized bed [25].
A comparison between a macro-scale model of the fluidized bed reactor for chemical looping combustion of methane, without gas separation membranes, developed in Aspen Plus with a sequence of CSTRs and PFRs, and a micro-scale CFD model is performed by Porrazzo et al. [26], reporting how most of the units in the Aspen Plus model must be used to simulate the bottom of the reactor, where the evolution of the bubble phase is faster (percentage increase of the average bubble diameter) to obtain a better matching with the CFD model.

Mahecha-Botero et al. [27] developed models of increasing complexity to simulate fluidized beds with perm-selective membranes (planar geometry) and to identify the most suitable fluidization regime for the reactor operation. The regimes are defined, and their properties weighted, on a stochastic basis. They found that the turbulent regime outperforms the bubbling regime because the vigorous mixing overcomes the mass transfer limitation of bubbling beds, while the fast fluidization regime, despite its similar performance to the turbulent one, operates at higher velocities, with higher risks of catalyst elutriation and losses and membranes wearing. Also the transition from the bubbling to the turbulent regime in strongly comparted beds, like those with immersed membranes, has to be investigated, since the most common empirical formulations for the transition velocity overestimate its value compared to CFD simulations [28].

When dealing with fluidized bed membrane reactors the focus is generally on the hydrodynamics of the bed, while limited attention is devoted to the permeation process across the membrane: Sieverts' law, with a permeability retrieved by permeation tests is applied, independently from the permeate side configuration (with or without sweep gas). For supported membranes, either on metallic or ceramic substrates, the permeation flux must be computed considering the actual hydrogen pressure at the membrane inner and outer surfaces. At the inner surface, it is very close to the bulk value in the case without sweep gas (often at sub-atmospheric pressure), but it can be much higher when a sweep gas is used, due to the gas diffusion resistance in the porous support. At the outer surface, the main limitations arise from 
the so called concentration polarization losses, i.e. local hydrogen partial pressure lower than the bulk value, due to slow gas diffusion (or ineffective mixing in the case of fluidized beds).

Caravella et al. [29] describe the diffusion process across a $1 \mu \mathrm{m}$ membrane deposited on a $1.5 \mathrm{~mm}$ multilayer porous support (five layers with pore diameters from $5 \mathrm{~nm}$ to $50 \mu \mathrm{m}$ ): gas diffusion in the porous support can cause up to about $40 \%$ of the overall hydrogen pressure drop from the bulk of the retentate to the permeate side; if the selective layer thickness increases to $10 \mu \mathrm{m}$ the contribution of the same porous support is around $30 \%$. This analysis in the trans-membrane direction, to be applied to membrane reactor cases needs to be extended in the axial direction, where the hydrogen fraction significantly changes along the permeate side. Furthermore, equations are considered for a planar geometry while in our applications we exploit tubular membranes. A completely different weight (only few percentage points) is assigned to the support losses by Peters et al. [30], who experimentally tested hydrogen permeation on a thin Pd-Ag membrane on a metallic support (316L stainless steel, $0.48 \mathrm{~mm}$ thickness, $2 \mu \mathrm{m}$ pore size) using helium as sweep gas, while most of the penalty is associated to the concentration polarization losses (around 80\%).

Other aspects to be considered in membrane reactors are (i) the possible interaction of the catalyst with the membrane, which can inhibit the permeation by surface poisoning of the membrane [31]; (ii) the mechanical resistance of catalyst particles to crumble, which, over time, would reduce the average particles diameter and shift the bed to a different fluidization regime; (iii) the resistance of the membrane to erosion, causing local pinholes of the selective layer and hence decreasing the selectivity. These issues can be solved, as demonstrated by Helmi et al. [32] who successfully operated a fluidized bed membrane reactor for high-temperature WGS for $900 \mathrm{~h}$ without significant losses of permeability nor selectivity.

In the present work, a flexible model of a fluidized bed membrane reactor in the bubbling regime is developed in the Aspen Custom Modeler environment. Key features are flexibility to feedstock (i.e. natural gas, bio-gas or bio-ethanol), reforming reactions (chemical equilibrium, different kinetic schemes), detailed hydrodynamics of the bubble and emulsion phases, different options on the permeate side (vacuum or sweep gas, including gas diffusion limitations in the porous support). The options of the model are first set to reproduce the results of a well-established model [8] used as reference, with natural gas feeding and vacuum at the permeate side, for the validation of the hydrodynamics. After that, the model is extended for the case with sweep gas at the permeate side and the properties of the porous support are retrieved from experimental data. Finally the model is applied for the case of ethanol auto-thermal reforming with vacuum and with sweep gas at the permeate side, which is the application described in Ref. [14] for a $5 \mathrm{~kW}_{\mathrm{el}} \mathrm{m}$-CHP system developed within the Fluidcell project [3]. This model can be imported in Aspen Plus and Aspen Plus Dynamics, therefore beyond the analysis of many configurations of membrane reactors, it is a valuable tool for the integration with complex systems, from small- and medium-scale hydrogen production units to m-CHP systems with PEM fuel cells.

\section{Model features}

A phenomenological model of membrane reactor is developed in Aspen Custom Modeler (ACM), which allows the integration of custom and standard components in Aspen Plus and Aspen Plus Dynamics for steady-state and dynamic simulations of complex chemical/energy systems. Advantages of ACM are the fast coding (that allows a quick switch of the problem from design to simulation conditions by changing the "state" of the variables of the problem) and the computation of thermodynamic and transport properties of pure species or mixtures by calling a large variety of internal sub-routines; main drawback is the poor control of the user on the solving procedure (e.g. there are no debug functions).

The bed is divided into three main regions, which lengths can be set by the user: the first region at the bottom of the reactor is dedicated to the oxidation and reforming reactions, the middle region is occupied by the membranes (permeation zones); the last section is a buffer region that mainly corresponds to the free-board region depending on the initial bed height and expansion. The scheme of the ACM model is depicted in Fig. 1.

Correlations for the fluid-dynamic aspects of the bed are substantially the same as in the model developed by TU/e [8] (hereafter named Delphi model, from the software used for the coding) used as reference for the validation of the new model in the bubbling regime with the "simple two-phase model". The complete list of mass and energy balances, and fluid-dynamic equations for the bubbling bed are listed in Table 1. Mass and energy balances are coded including the unsteady terms, but all the simulations here reported are performed only at steady-state.

The interaction between the bubbles and the membranes is still a topic of research, therefore different schemes have been implemented to simulate their behavior in the membranes region: (i) bubbles grow not limited by the membranes (no interaction at all); (ii) bubbles breakup and are limited to the distance between the membranes (as assumed in Delphi model); (iii) bubbles do not break and, if at the beginning of

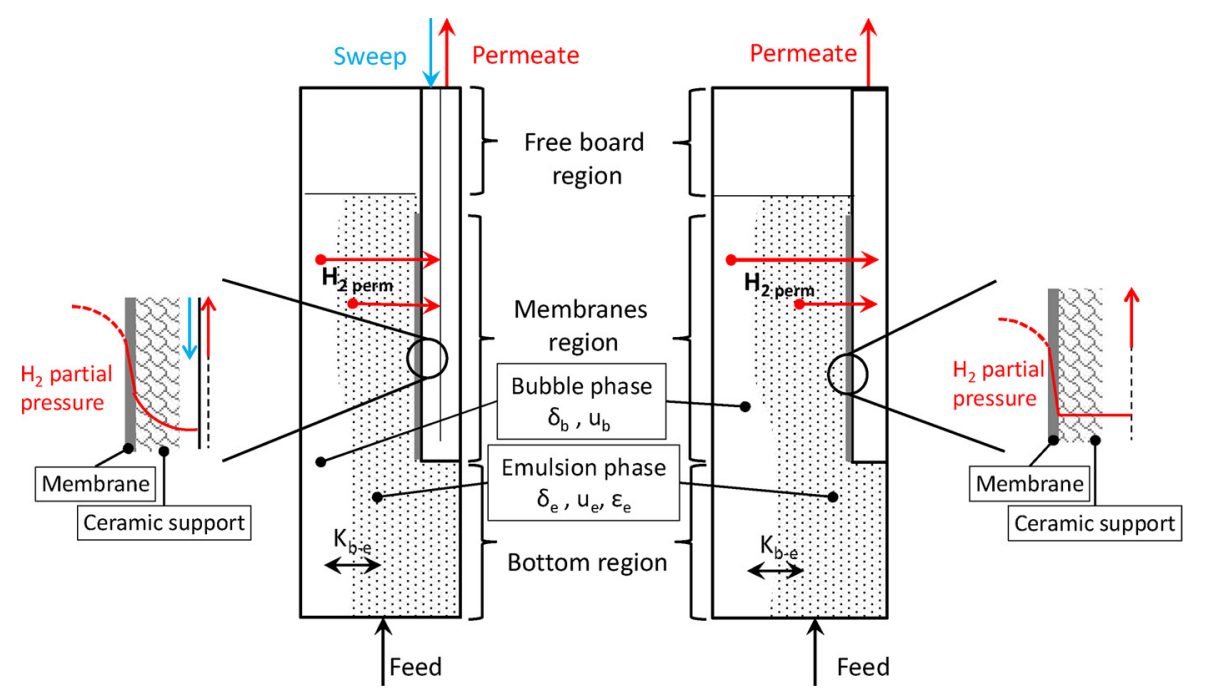

Fig. 1. Scheme of fluidized bed membrane reactor developed in ACM for the cases with and without sweep gas. 
Table 1

Equations of the model in AMC.

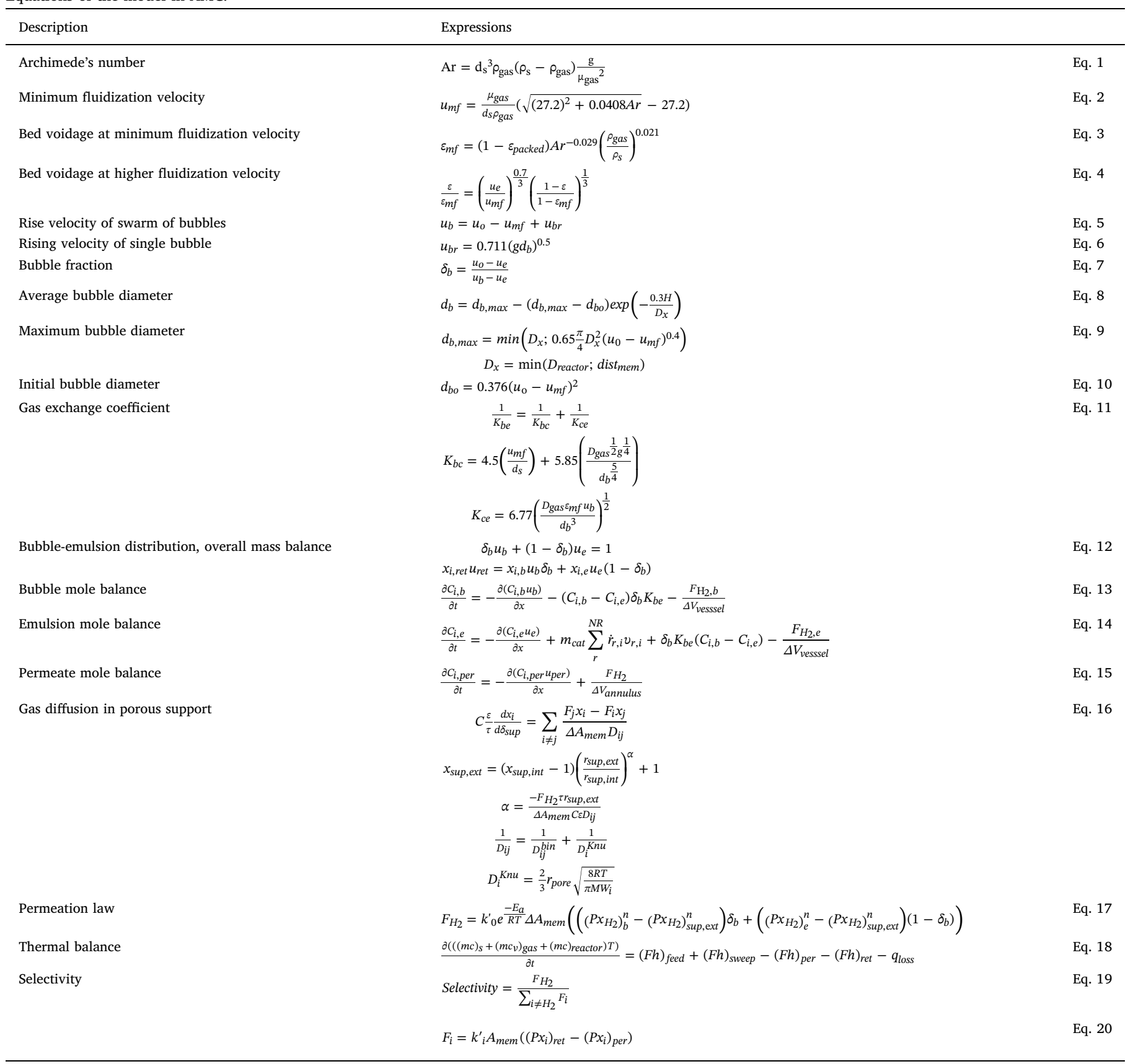

the membranes region are smaller than the membranes distance, grow limited to this distance, if bigger grow unlimited. The results presented in this paper are based on assumption (ii), which is described by (Eq. (9)).

The membranes are made of a tubular ceramic support on the external side of which a thin Pd-Ag alloy layer is applied. Gas diffusion in the support is modeled by simplified Stefan-Maxwell equations (Eq. (16)): the pressure gradient is neglected and the effective gas diffusivity includes both the molecular and the Knudsen diffusion contributions. The equations applied to a two-species mixture (hydrogen and the sweep gas) reduce to Fick's law for non-stationary media and are then integrated for the specific case of cylindrical geometry.

Hydrogen is assumed to be extracted from both the bubble and the emulsion phase, weighted on the local phase composition and extension of the two phases (Eq. (17)). In this work the hydrogen flux reduction due to the polarization concentration losses is neglected.

Another important parameter is the selectivity of the membranes, i.e. the capability of producing pure hydrogen without other contaminants. The reasons of loss of selectivity can be defects of the thin Pd-based layer or degradation of the sealing ferrules in the connections between the membrane tubes. The overall selectivity of the membrane reactor (Eq. (19)), and hence the impurities concentration in the permeate stream, can be estimated using the average partial pressure of each specie along the membrane region and a global permeance $\mathrm{k}_{\mathrm{i}}$ (Eq. (20)).

Three schemes of reactions are implemented and can be chosen by the user: (i) chemical equilibrium by Gibbs energy minimization of a set of chemical species $\left(\mathrm{CH}_{4}, \mathrm{CO}, \mathrm{CO}_{2}, \mathrm{H}_{2}, \mathrm{H}_{2} \mathrm{O}\right)$ by two reactions (MSR and WGS); (ii) methane oxidation, reforming and water gas shift with kinetic laws from Trimm and Lam [33] and Numaguchi and Kikuchi [34], 
(iii) ethanol oxidative steam reforming with kinetic laws from the FluidCELL project [35].

Solid particles can be distinguished between the catalyst and the filler material. The filler is chemically inert, made of the same material as the support of the catalyst. Only spherical particles with the nominal diameter are considered.

The model considers a perfectly isothermal bed and the operative temperature results from the global energy balance between the inlet and outlet material streams and the heat losses to the ambient (Eq. (18)). The hypothesis of isotherm is coherent with preliminary tests running on the prototype of the membrane reactor. Anyway, a future improvement will focus on the modeling of the upward and downward motion of the solids for a more accurate thermal balance and prediction of possible temperature distribution, especially to simulate the start-up of the reactor.

The performance of the membrane reactor is described by the hydrogen recovery factor (HRF), defined as the moles of hydrogen permeated over the theoretical recoverable number of hydrogen moles of the complete reforming of the feed (e.g. 6 per each mole of ethanol, 4 for methane).

\section{Comparison of ACM model with Delphi model}

The ACM model is compared for the case of methane oxidative steam reforming with vacuum on permeate side with the Delphi model from Ref. [8], which relies on years of experiments and validation tests.

The geometry of the reactor, the operation conditions and the feed streams have been set the same for the two models to obtain the hydrogen production targets set in the Fluidcell project (about $3 \mathrm{Nm}^{3} / \mathrm{h}$ ). Main results as the evolution of gas velocities, gas distribution in bubble and emulsion phases, bubbles size, species flow rate, permeated hydrogen and retentate flow rate values are compared. Feed stream and reactor parameters are listed in Table 2. The feed stream consists of methane, steam and air at the same pressure and temperature of the reactor; the reactor is adiabatic, isobaric and isothermal. Reactor diameter is $0.2 \mathrm{~m}$, with 32 membranes $\left(0.4 \mathrm{~m}^{2}\right)$ submerged in the fluidized bed at a distance of $0.02 \mathrm{~m}$ (surface to surface).

For the base-case, the relative error on the amount of permeated hydrogen is $1.15 \%$ which is the most important result; for the single species in the retentate stream the relative error is below $6 \%$. Very good agreement is obtained also for the trend of the velocities and bed properties, as depicted in Fig. 2 for the base case. It is worth to mention the discontinuity of properties of the bubble phase at the beginning of the membrane region (at reactor height $0.2 \mathrm{~m}$ ), where the bubbles break-up because the membranes obstacle their growth. From a mathematical point of view, this effect is due to the change in the reference diameter $\left(D_{x}\right.$ in Eq. (9)) and leads to bubbles break-up even if they are smaller than the maximum dimension allowed. The small differences between the ACM and Delphi models are attributed to the difference in the computation of the transport properties of the gas mixture (viscosity, binary and mixture diffusivity), in fact the Delphi model uses correlations that may differ from those implemented in the Aspen libraries.

\section{Permeation law and porous support parameters calibration}

The membrane support can play a key role in the overall permeation process when sweep gas is applied. An experimental campaign to investigate its influence, and then calibrate the developed model, has been performed on a single-membrane rig. The Pd-Ag layer $(4.5 \mu \mathrm{m})$ was deposited onto a ceramic multilayer porous support (ID $=7 \mathrm{~mm}$; $\mathrm{OD}=1.028 \mathrm{~mm}$, total membrane area $=0.0044 \mathrm{~m}^{2}$ ). The membrane was first tested with pure hydrogen, pressurized on the feed side, and with atmospheric pressure on the permeate side at different temperatures (Fig. 3). Then, nitrogen at different flow rates was added as sweep gas to the permeate side (Fig. 4a). Parameters of the permeation law (permeability $\mathrm{k}_{0}$, permeance $\mathrm{k}_{0}{ }^{\prime}$, apparent activation energy $\mathrm{E}_{\mathrm{a}}$ ), are retrieved from the experimental data of the first test by a linearization of the Sieverts' permeation law (Eqs. (21) and (22)) and compared with other values from literature related to ceramic supported membranes (Table 3).

$$
\begin{gathered}
F_{\mathrm{H}_{2}}=\mathrm{k}_{0} e^{\frac{-E_{a}}{R T} \frac{\left(P_{\mathrm{H}_{2}, \text { feed }}{ }^{0.5}-P_{\mathrm{H}_{2}, \text { perm }}{ }^{0.5}\right)}{\delta}} \mathrm{A}_{\mathrm{mem}} \\
\mathrm{F}_{\mathrm{H}_{2}}=\mathrm{k}_{0}^{\prime} \mathrm{e}^{\frac{-\mathrm{E}_{\mathrm{a}}}{\mathrm{RT}}}\left(\mathrm{P}_{\mathrm{H}_{2}, \text { feed }}{ }^{0.5}-\mathrm{P}_{\mathrm{H}_{2}, \text { perm }}{ }^{0.5}\right) \mathrm{A}_{\mathrm{mem}} \\
\mathrm{F}_{\mathrm{H}_{2}}=\mathrm{k}(\mathrm{T})\left(\mathrm{P}_{\mathrm{H}_{2}, \text { feed }}{ }^{0.5}-\mathrm{P}_{\mathrm{H}_{2}, \text { perm }}{ }^{0.5}\right) \mathrm{A}_{\text {mem }} \\
\mathrm{y}=\frac{\mathrm{Ax}+\mathrm{b}=\mathrm{A}^{\prime} \mathrm{x}+\mathrm{b}}{\left(\mathrm{P}_{\mathrm{H}_{2}, \text { feed }}{ }^{0.5}-\mathrm{P}_{\mathrm{H}_{2}, \text { perm }}{ }^{0.5}\right) \mathrm{A}_{\mathrm{mem}}} \\
\mathrm{A}=\ln \left(\mathrm{k}_{0}\right) \\
\mathrm{A}^{\prime}=\ln \left(\mathrm{k}_{0}^{\prime}\right)=\ln \left(\frac{\mathrm{k}_{0}}{\delta}\right) \\
\mathrm{x}=\frac{1}{\mathrm{RT}} \\
\mathrm{b}=-\mathrm{E}_{\mathrm{a}}
\end{gathered}
$$

These values are then used in the permeation law of the singlemembrane gas separator, to match the experimental data with sweep gas through the calibration of microscopic properties of the ceramic support. It is worth to mention that the effect of increasing the sweep flow rate appears only when the pressure difference between the feed and the permeate side is small, while its effect becomes lower when increasing the feed pressure. In fact, in our experiments, at $\mathrm{P}_{\text {feed }}=2.5$ bar and $\mathrm{P}_{\text {perm }}=1$ bar the permeate flow rate is already independent from the sweep flow rate (Fig. 4a).

Due to the multilayer structure of the support, the values obtained from the calibration are representative of equivalent properties of the multilayer structure (porosity, tortuosity and pore size in Table 3). Both porosity and pore radius obtained are compatible with the manufacturer data [39], while there are no data for the tortuosity. Anyway it must be outlined that from a mathematical point of view the problem is under-constrained, therefore several combination of these parameters are possible. The agreement between the predicted and the experimentally determined hydrogen permeate flow rates is good: the deviation is below $4 \%$ for the case with the lowest sweep flow rate and feed pressure, and below $2 \%$ for the case with the highest sweep flow rate and feed pressure (Fig. $4 \mathrm{~b}$ ).

Despite the hydrogen permeance has been experimentally determined here $\left(\mathrm{k}_{0}{ }^{\prime}=0.00315 \mathrm{~mol} /\left(\mathrm{s} \mathrm{m}^{2} \mathrm{~Pa}^{0.5}\right)\right.$ at $\left.500{ }^{\circ} \mathrm{C}\right)$, in the simulations of the next sections the same value used in Ref. [14] for the ideal model is adopted $\left(\mathrm{k}_{0}{ }^{\prime}=0.00273 \mathrm{~mol} /\left(\mathrm{s} \mathrm{m}^{2} \mathrm{~Pa}^{0.5}\right)\right.$ at $\left.500{ }^{\circ} \mathrm{C}\right)$ in order to obtain a fair comparison.

\section{Application of the model to ethanol auto-thermal reforming}

After its validation against similar models and experimental results, the ACM membrane reactor model is subsequently applied to the case of low-temperature $\left(500{ }^{\circ} \mathrm{C}\right)$ ethanol auto-thermal reforming. Both the options with vacuum or with sweep gas on the permeate side are analyzed and compared with the results of the ideal reactor used in the preliminary analysis of a m-CHP system in Ref. [14]. Feed stream and

Table 2

Parameters for the membrane reactor model validation: nominal conditions and range for sensitivity analysis.

\begin{tabular}{lll}
\hline Parameter & Base case, range & Maximum deviation in $\mathrm{H}_{2}$ output \\
\hline $\mathrm{S} / \mathrm{C}[-]$ & $1.8 ; 1.8-3$ & $1.5 \%$ \\
$\mathrm{u}_{0} / \mathrm{u}_{\mathrm{mf}}[-]$ & $4 ; 3-6$ & $3.4 \%$ \\
$\mathrm{~T}$ reactor $\left[{ }^{\circ} \mathrm{C}\right]$ & $600 ; 500-650$ & $3.2 \%$ \\
$\mathrm{P}$ feed $[\mathrm{bar}]$ & $10 ; 8-12$ & $2.2 \%$ \\
P permeate $[\mathrm{bar}]$ & $0.3 ; 0.2-0.4$ & $1.8 \%$
\end{tabular}



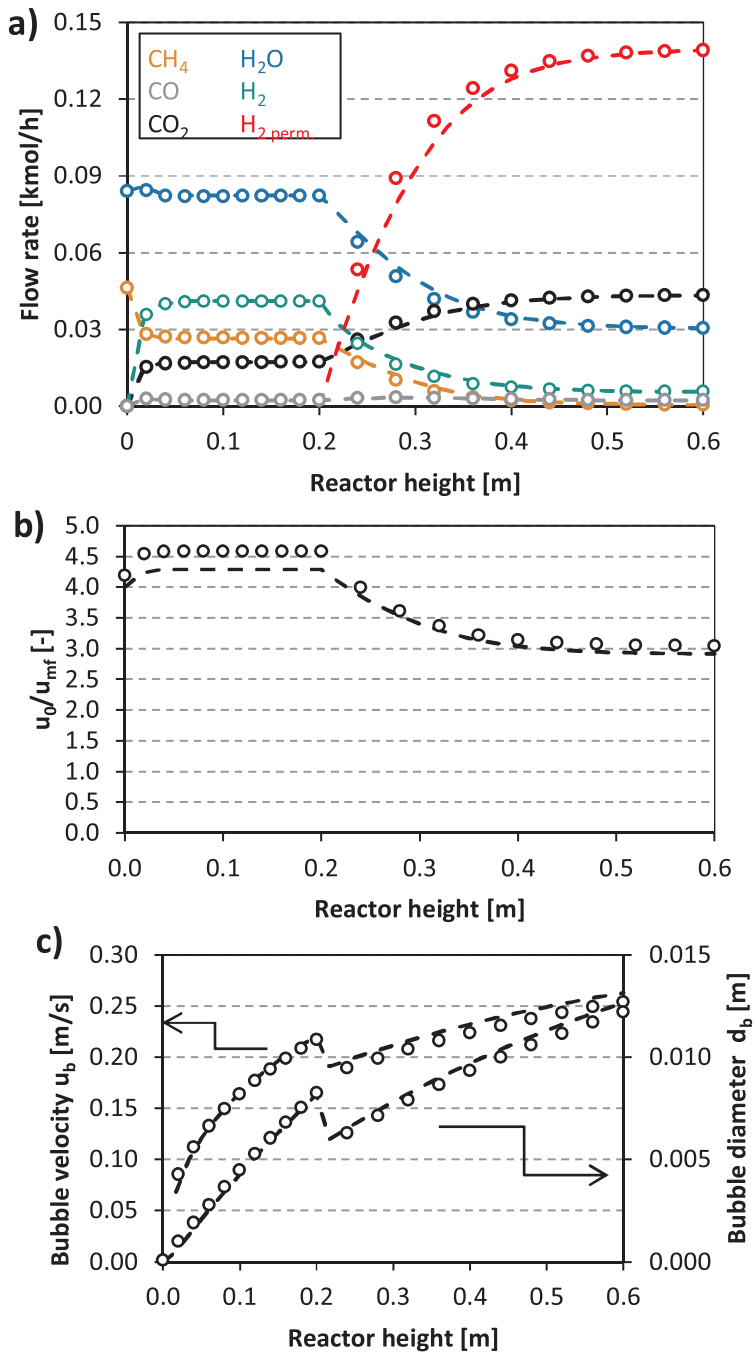

Fig. 2. Comparison of profiles between ACM (dots) and Delphi (lines) models along the reactor height. a) species molar flow rate; b) $\mathrm{u}_{0} / \mathrm{u}_{\mathrm{mf}}$; c)bubble velocity and diameter.

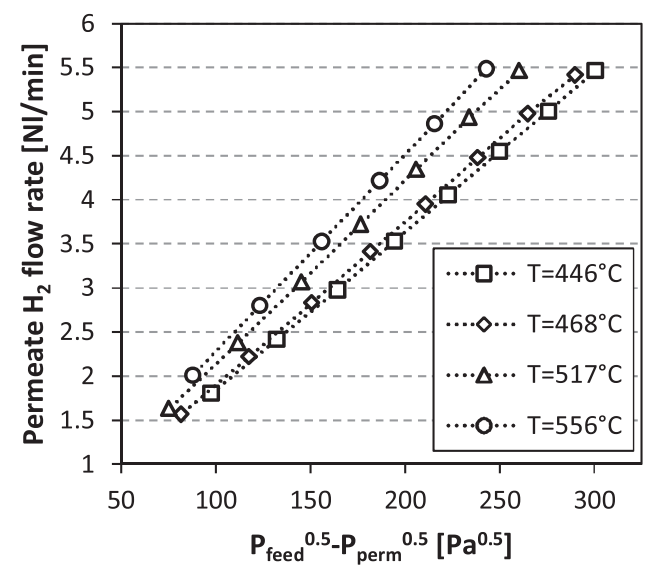

Fig. 3. Hydrogen permeation test without sweep gas $\left(\mathrm{P}_{\mathrm{perm}}=1 \mathrm{bar}\right)$.

reactor conditions are summarized in Table 4. Some upgrades with respect to the Delphi model are implemented in the ACM model: the emulsion phase is more expanded than in minimum fluidization conditions, the bed is not isobaric but hydrostatic and friction pressure drops are included, the reactor is not adiabatic but heat losses to the environment are considered. The comparison between the ideal model and the detailed model is performed for different reactor sizes, which determine different $\mathrm{u}_{0} / \mathrm{u}_{\mathrm{mf}}$ ratio and finally the global performance. The water-ethanol feed stream, the operation conditions (temperature and pressure) and the geometry of the reactor (vessel diameter, membranes distance and area) are fixed, the air flow rate is set to close the energy balance, while the conditions of the fluidized bed and the hydrogen output are computed. The reactor design considers the spacing between the membranes: the distance between the surface of two membranes decreases with the size of the reactor and limits the growth of the bubbles along the bed. The fluidized bed is assumed to expand always at the same height of the membranes, therefore with a variable total amount of catalyst, depending on the emulsion void fraction and the bubble phase extension. The solid inventory is made by $50-50 \%$ of active catalyst and filler material. The kinetic laws for ethanol autothermal reforming are taken from [35] and consider the following steps: ethanol oxidation to deplete all the oxygen; complete and immediate decomposition of the rest of ethanol into methane, carbon monoxide and hydrogen; reforming of methane and water gas shift. The reforming occurs in the backward direction due to the initial high hydrogen fraction caused by ethanol decomposition till the equilibrium composition is reached in the bottom part of the reactor; finally forward MSR and WGS occur in the membrane region, as depicted in Fig. 5.

For the case with vacuum at the permeate side, the hydrogen output of the detailed model is almost $3 \mathrm{Nm}^{3} / \mathrm{h}$ compared with $3.2 \mathrm{Nm}^{3} / \mathrm{h}$ predicted by the simple model, with a difference generally below $10 \%$, depending on reactor diameter $(0.12-0.28 \mathrm{~m})$, as depicted in Fig. 6 . To reach the desired output, it is necessary to increase the membrane area by $25 \%$, from $0.290 \mathrm{~m}^{2}$ to $0.364 \mathrm{~m}^{2}$. The HRF spans in the range $56-65 \%$ with $0.29 \mathrm{~m}^{2}$ and $59-68 \%$ with $0.364 \mathrm{~m}^{2}$ respectively, according to the large changes in the $\mathrm{u}_{0} / \mathrm{u}_{\mathrm{mf}}$ ratio (2.5-20). The $\mathrm{O}_{2} / \mathrm{EtOH}$ ratio increases with the hydrogen output, to sustain the reforming reactions, and is in good agreement with the value estimated with the simple model (about 0.4). In the case of small reactor diameter (high gas velocity) the membranes first brakes the bubbles, then limit their size, which is always well below the maximum value set by the geometric constrain (Fig. 7a). In the case of large reactor diameter, bubbles in membrane region are slower (even if bigger), and do not limit the reactor operation because the fraction of gas that flows through the bubble phase strongly reduces, e.g. from $95 \%$ to $60-70 \%$ of the case with $D_{\text {reactor }}=0.12 \mathrm{~m}$ and $0.28 \mathrm{~m}$ respectively (Fig. $7 \mathrm{~b}$ ).

The same analysis is repeated for the case with sweep gas on the permeate side. In a real micro-CHP system, steam would be adopted as sweep gas, because it's more accessible and easy to be separated from the hydrogen by condensation. Using sweep gas, the energy balances of the m-CHP system changes and the hydrogen required is $3.16 \mathrm{Nm}^{3} / \mathrm{h}$, resulting in an ideal membrane area of $0.370 \mathrm{~m}^{2}$ when the Sweep/EtOH molar ratio is 1.6 and $12 / 1.3$ bar as feed/permeate pressures. First, the comparison between the ideal and the detailed models is performed neglecting the gas diffusion in the porous support, which corresponds to using the bulk hydrogen partial pressure to compute the local flux: in this case the hydrogen output is very close to the ideal case (Fig. 8). When the diffusion limitations are included according to Eq. (16), the difference becomes remarkable with a reduction around 55\% compared to the ideal model. Overall results are shown in Fig. 8. The $\mathrm{u}_{0} / \mathrm{u}_{\mathrm{mf}}$ ratio spans from the minimum value close to 1.5 , i.e. bed close to smooth fluidization with the largest diameter, to the maximum of 12 with the smallest diameter. Due to the great differences in the hydrogen permeation also the thermal balance of the reactor changes, in fact the $\mathrm{O}_{2}$ / EtOH ratio in the case with diffusion limitations is lower (below 0.2 ) than in the case without limitations, which in its turns is close to the ideal one (around 0.4).

The hydrogen output does not increase to the desired value neither by decreasing the pressure of the permeate side from 1.3 to 1.2 bar and by increasing the membranes surface area by $25 \%$ (from 0.37 to $0.46 \mathrm{~m}^{2}$ ), since the gas transfer limitation in the support dominates.

As last part of the work, due to the large differences between the 

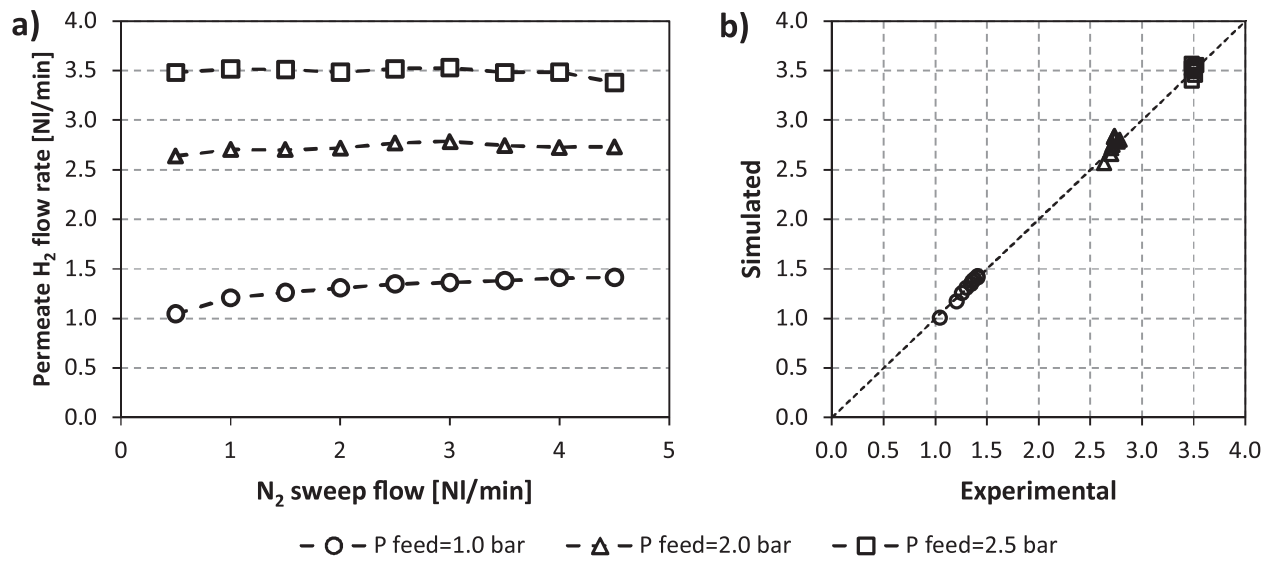

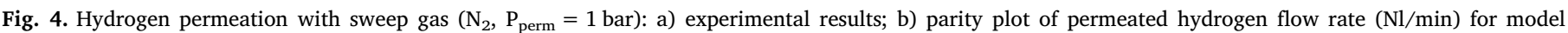
calibration.

Table 3

Membranes properties.

\begin{tabular}{|c|c|c|c|c|}
\hline Parameter & This work & {$[36]$} & [37] & [38] \\
\hline $\begin{array}{l}\text { Membrane thickness } \\
\quad[\mu \mathrm{m}]\end{array}$ & 4.5 & 2.5 & 4 & 7 \\
\hline $\mathrm{k}_{0}[\mathrm{~mol}$ & 0.01535 & - & - & - \\
\hline $\begin{array}{l}\mathrm{k}_{0}^{\prime}[\mathrm{mol} \\
\left.\quad \mathrm{s}^{-1} \mathrm{~m}^{-2} \mathrm{~Pa}^{-\mathrm{n}}\right]\end{array}$ & $6.6510^{-8}$ & $13.5210^{-8}$ & $6.9310^{-8}$ & - \\
\hline $\begin{array}{l}\mathrm{k}\left(500^{\circ} \mathrm{C}\right)[\mathrm{mol} \\
\left.\quad \mathrm{s}^{-1} \mathrm{~m}^{-1} \mathrm{~Pa}^{-\mathrm{n}}\right]\end{array}$ & 0.00315 & 0.00394 & 0.00366 & 0.00104 \\
\hline $\mathrm{E}_{\mathrm{a}}\left[\mathrm{J} \mathrm{mol}^{-1}\right]$ & 10171 & 16816 & 9990 & 11400 \\
\hline $\mathrm{n}$ & 0.5 & 0.5 & 0.5 & 0.54 \\
\hline support & $\begin{array}{l}\text { Multilayer ceramic, } \\
1.5 \mathrm{~mm} \text { thickness, } \\
\alpha-\mathrm{Al}_{2} \mathrm{O}_{3}\end{array}$ & ceramic & ceramic & ceramic \\
\hline Porosity $(\varepsilon)[-]$ & 0.48 & - & - & - \\
\hline Tortuosity $(\tau)[-]$ & 3.2 & - & - & - \\
\hline Pore radius $\left(r_{p}\right)[n m]$ & 360 & - & - & - \\
\hline
\end{tabular}

Table 4

Feed stream and reactor conditions for the vacuum and sweep gas cases.

\begin{tabular}{lll}
\hline & Vacuum case & Sweep gas case \\
\hline Feed stream conditions & & \\
EtOH feed & $0.046 \mathrm{~mol} \mathrm{~s}^{-1}$ & $0.046 \mathrm{~mol} \mathrm{~s}^{-1}$ \\
$\mathrm{H}_{2} \mathrm{O} / \mathrm{EtOH}$ & 3.6 & 3.6 \\
Sweep/EtOH & - & 1.6 \\
Temperature & $434^{\circ} \mathrm{C}$ & $434^{\circ} \mathrm{C}$ \\
Pressure & $6 \mathrm{bar}$ & $12 \mathrm{bar}$ \\
Reactor conditions & & \\
Temperature & $500{ }^{\circ} \mathrm{C}$ & $500{ }^{\circ} \mathrm{C}$ \\
Pressure (vessel/permeate side) & $6 / 0.3 \mathrm{bar}$ & $12 / 1.1 \mathrm{bar}$ \\
Membranes area & $0.29 \mathrm{~m}^{2}$ & $0.37 \mathrm{~m}^{2}$ \\
\hline
\end{tabular}

ideal reactor and the detailed model for the sweep gas case, a sensitivity analysis is performed on the parameters Sweep/EtOH ratio and support thickness, assuming the increased membrane area $\left(0.46 \mathrm{~m}^{2}\right)$ and the lower permeate pressure ( 1.2 bar). Results of the hydrogen partial pressure profiles along the reactor, in the permeate stream and at the support-membrane interface and along the reactor are depicted in Fig. 9 and Fig. 10 respectively. The hydrogen permeated increases by increasing the sweep flow rate, but the gain is small when moving to high flowrates: the hydrogen output increases from 1.73 to 1.82 to $1.94 \mathrm{Nm}^{3} / \mathrm{h}$ when the Sweep/EtOH ratio is $1,1.6$ and 3 . The maximum sweep gas flow rate is set by two limits: the heat available at system level to produce the steam and the pressure drop in the membrane tubes (which are mainly concentrated in the upcoming internal pipe visible in

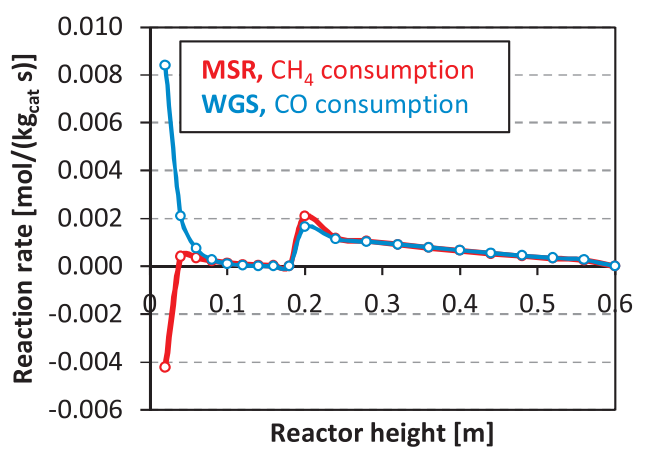

Fig. 5. Reaction rate profiles of methane steam reforming (MSR) and water gas shift (WGS).

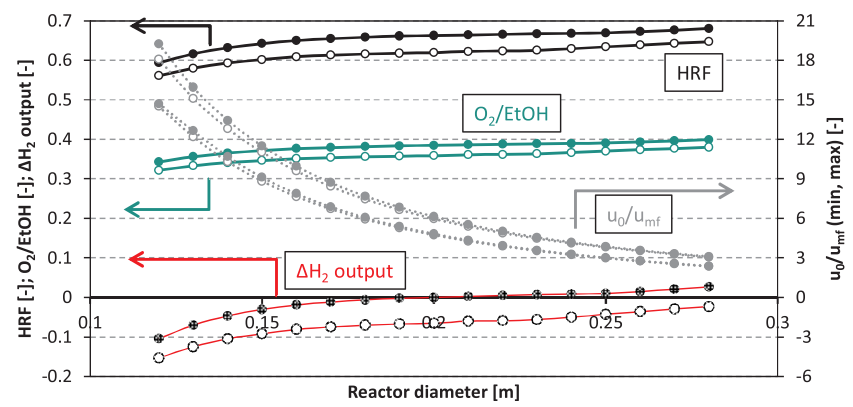

Fig. 6. Results of the vacuum case for different reactor diameters (empty dots refer to the case with $A_{\text {mem }}=0.29 \mathrm{~m}^{2}$; full dots to the case with $A_{\text {mem }}=0.364 \mathrm{~m}^{2}$ ).

Fig. 1 where all the permeate stream flows toward the exit).

The reduction of the thickness of the support leads to a large increase in the hydrogen production that grows from 1.82 to 2.1 and $2.5 \mathrm{Nm}^{3} / \mathrm{h}$ when the support thickness is $1.5,1.0$ and $0.5 \mathrm{~mm}$. On the other side it is necessary to point out that the thinner the support the lower its mechanical resistance, which is the most critical aspect of handling ceramic supported membranes during the assembly of the reactor. For these reasons thicker supports are required and the low hydrogen production capacity must be addressed by changing other operation parameters.

For the case of sweep gas, in order to increase the hydrogen production to the desired value it is not enough just to act on the membrane surface, but also the operation conditions must be changed, e.g. increasing the feed pressure, the sweep flowrate and decreasing the permeate pressure. These modifications affect the overall process in which the membrane reactor is integrated and a complete analysis of 

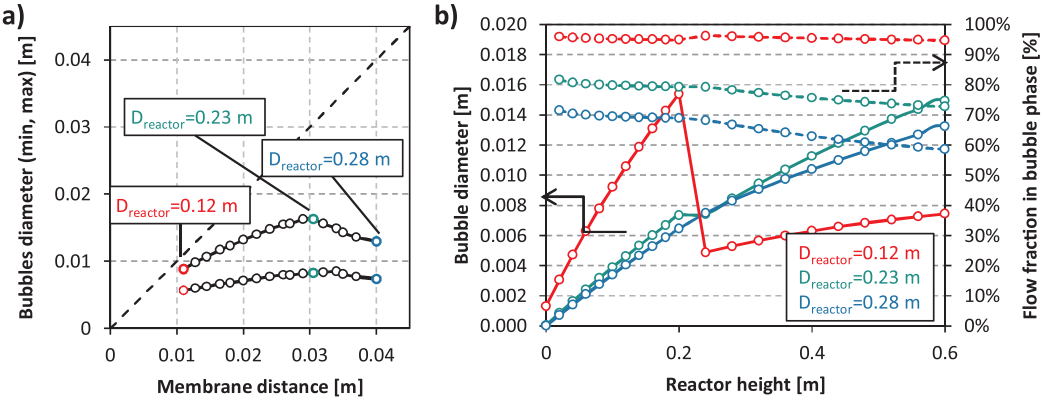

Fig. 7. Bubbles characteristics: a) minimum and maximum bubble diameter in membrane region compared with the membrane distance (case with $0.29 \mathrm{~m}^{2}$ ); b) profiles of bubbles diameter and gas flow fraction in bubble phase for some reactor diameters.

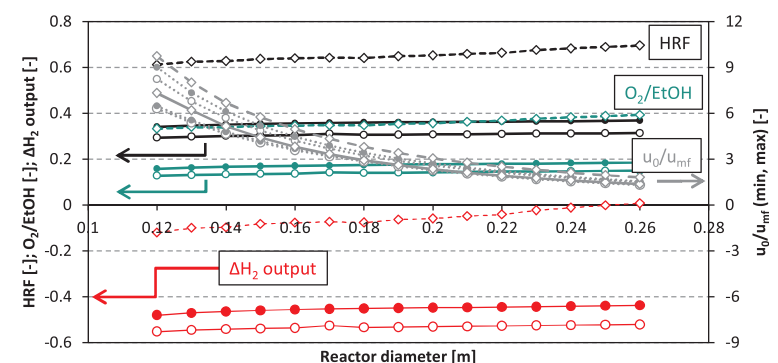

Fig. 8. Results of the sweep gas case for different reactor diameters. Dotted line: neglecting diffusion effect of the porous support; continuous line: including diffusion effect in the porous support; empty dots refer to the case with $\mathrm{A}_{\mathrm{mem}}=0.37 \mathrm{~m}^{2}$ and $\mathrm{P}_{\mathrm{perm}}=1.3 \mathrm{bar}$; full dots refer to the case with $\mathrm{A}_{\mathrm{mem}}=0.46 \mathrm{~m}^{2}$ and $\mathrm{P}_{\mathrm{perm}}=1.2$ bar.

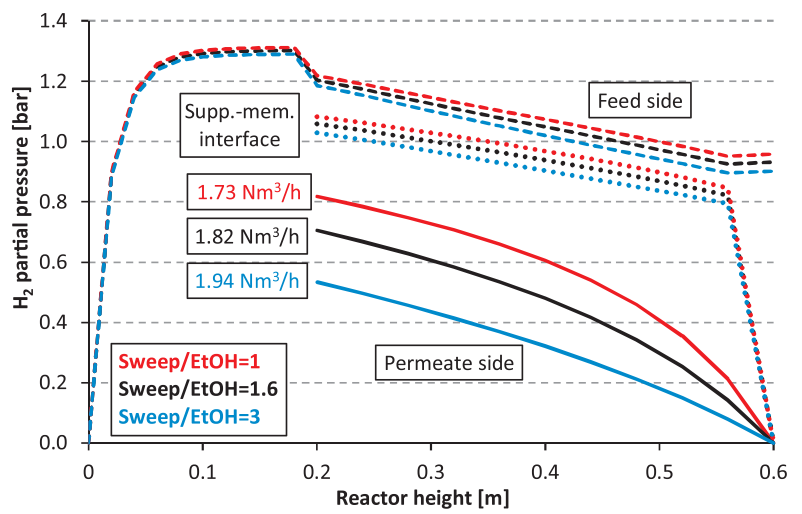

Fig. 9. Effect of Sweep/EtOH ratio on hydrogen partial pressure profiles $\left(D_{\text {reactor }}=0.2 \mathrm{~m} ; \delta_{\text {supp }}=1.5 \mathrm{~mm}\right)$.

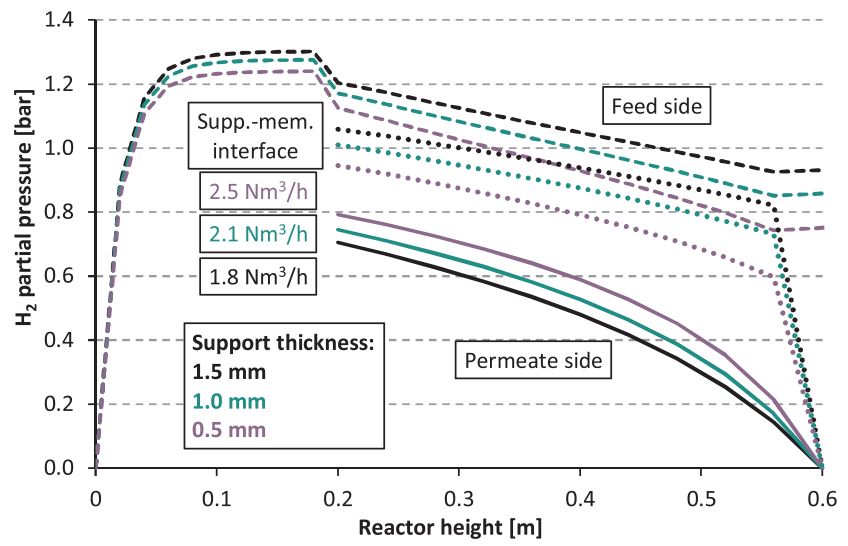

Fig. 10. Effect of support thickness on hydrogen partial pressure profiles $\left(D_{\text {reactor }}=0.2 \mathrm{~m}\right.$; Sweep/EtOH $\left.=1.6\right)$. the system is required, but it is beyond the scope of this work.

\section{Conclusions}

This work presented a model of a fluidized bed membrane reactor for small-scale hydrogen production developed in Aspen Custom Modeler. The model includes reforming reactions (chemical equilibrium, different kinetic schemes), detailed hydrodynamics of the bubble and emulsion phases, different options on the permeate side (vacuum or sweep gas). Previous works outlined the importance of accounting for detailed hydrodynamic phenomena in the reaction side to prevent hydrogen flux over-estimation, while in this work also the effect of gas diffusion in the membrane support has been addressed. The model was firstly validated against another well-established model for the vacuum configuration, while experimental results were used for the sweep gas configuration. The model is then adopted to assess the performance of the membrane reactor fueled with bio-ethanol integrated into a micro-CHP system with PEM fuel cell.

The difference in the hydrogen output, for a fixed membrane area, compared to simpler models which do not account for the hydrodynamics and transport phenomena within the fluidized bed, ranges from $-10 \%$ up to $-55 \%$ for the cases with vacuum and sweep gas at the permeate side respectively. In particular for the case with sweep gas, the penalty is mainly due to the slow gas diffusion in the relatively thick supports of the membranes, which keeps the hydrogen partial pressure at the membrane interface much higher than in the bulk of the permeate, hence inhibiting the desired effect of the sweep gas.

\section{Acknowledgements}

The presented work is funded within the FluidCELL project as part of the European Union's Seventh Framework Programme (FP7/20072013) for the Fuel Cells and Hydrogen Joint Technology Initiative under grant agreement $n^{\circ}$ 621196. Note: "The present publication reflects only the authors' views and the FCH JU and the Union are not liable for any use that may be made of the information contained therein".

\section{References}

[1] Y. Shirasaki, I. Yasuda, Membrane reactor for hydrogen production from natural gas at the Tokyo Gas Company: a case study, Handb. Membr. React. React. Types Ind. Appl, Woodhead Publushing Limited, 2013, pp. 485-507, http://dx.doi.org/10. 1533/9780857097347.2.487.

[2] Ferret n.d. http://www.ferret-h2.eu/. (Accessed 21 July 2017).

[3] FluidCELL n.d. http://www.fluidcell.eu/. (Accessed 21 July 2017).

[4] Bionico n.d. http://www.bionicoproject.eu/.

[5] Reforcell n.d. http://www.reforcell.eu/. (Accessed 21 July 2017).

[6] G. Di Marcoberardino, L. Roses, G. Manzolini, Technical assessment of a microcogeneration system based on polymer electrolyte membrane fuel cell and fluidized bed autothermal reformer, Appl. Energy 162 (2016) 231-244, http://dx.doi.org/ 10.1016/j.apenergy.2015.10.068.

[7] G. Di Marcoberardino, G. Manzolini, Investigation of a $5 \mathrm{~kW}$ micro-CHP PEM fuel cell based system integrated with membrane reactor under EU natural gas quality, 
Int. J. Hydrogen Energy 42 (2017) 13988-14002, http://dx.doi.org/10.1016/j. ijhydene.2017.02.016.

[8] G. Di Marcoberardino, F. Gallucci, G. Manzolini, M. van Sint Annaland, Definition of validated membrane reactor model for $5 \mathrm{~kW}$ power output CHP system for different natural gas compositions, Int. J. Hydrogen Energy 41 (2016) 19141-19153, http://dx.doi.org/10.1016/j.ijhydene.2016.07.102.

[9] L. Roses, F. Gallucci, G. Manzolini, M. van Sint Annaland, Experimental study of steam methane reforming in a Pd-based fluidized bed membrane reactor, Chem. Eng. J. 222 (2013) 307-320, http://dx.doi.org/10.1016/j.cej.2013.02.069.

[10] a. Iulianelli, S. Liguori, T. Longo, S. Tosti, P. Pinacci, a. Basile, An experimental study on bio-ethanol steam reforming in a catalytic membrane reactor. Part II: Reaction pressure, sweep factor and WHSV effects, Int. J. Hydrogen Energy 35 (2010) 3159-3164, http://dx.doi.org/10.1016/j.ijhydene.2009.11.034.

[11] a. Basile, P. Pinacci, a. Iulianelli, M. Broglia, F. Drago, S. Liguori, et al., Ethanol steam reforming reaction in a porous stainless steel supported palladium membrane reactor, Int. J. Hydrogen Energy 36 (2011) 2029-2037, http://dx.doi.org/10.1016/ j.ijhydene.2010.11.020.

[12] M. De Falco, Ethanol membrane reformer and PEMFC system for automotive application, Fuel 90 (2011) 739-747, http://dx.doi.org/10.1016/j.fuel.2010.09.054.

[13] G. Manzolini, S. Tosti, Hydrogen production from ethanol steam reforming: energy efficiency analysis of traditional and membrane processes, Int. J. Hydrogen Energy 33 (2008) 5571-5582, http://dx.doi.org/10.1016/j.ijhydene.2008.06.029.

[14] S. Foresti, G. Manzolini, Performances of a micro-CHP system fed with bio-ethanol based on fluidized bed membrane reactor and PEM fuel cells, Int. J. Hydrogen Energy 41 (2015) 9004-9021, http://dx.doi.org/10.1016/j.ijhydene.2016.03.210.

[15] F. Gallucci, E. Fernandez, P. Corengia, M. van Sint Annaland, Recent advances on membranes and membrane reactors for hydrogen production, Chem. Eng. Sci. 92 (2013) 40-66, http://dx.doi.org/10.1016/j.ces.2013.01.008.

[16] L. Roses, F. Gallucci, G. Manzolini, S. Campanari, M. van Sint Annaland, Comparison between fixed bed and fluidized bed membrane reactor configurations for PEM based micro-cogeneration systems, Chem. Eng. J. 171 (2011) 1415-1427, http://dx.doi.org/10.1016/j.cej.2011.05.061.

[17] L. Roses, G. Manzolini, S. Campanari, CFD simulation of Pd-based membrane reformer when thermally coupled within a fuel cell micro-CHP system, Int. J. Hydrogen Energy 35 (2010) 12668-12679, http://dx.doi.org/10.1016/j.ijhydene. 2010.07.080.

[18] A. Acrivos, H. Brenner, J.E. Bailey, M. Morari, E.B. Nauman. Daizo Kuníí Fukuí Institute of Technology Octave Levenspiel Butterworth-Heinemann. n.d.

[19] L. Salemme, L. Menna, M. Simeone, G. Volpicelli, Energy efficiency of membranebased fuel processors -PEM fuel cell systems, Int. J. Hydrogen Energy 35 (2010) 3712-3720, http://dx.doi.org/10.1016/j.ijhydene.2010.01.096.

[20] L. Salemme, L. Menna, M. Simeone, Analysis of the energy efficiency of innovative ATR-based PEM fuel cell system with hydrogen membrane separation, Int. J. Hydrogen Energy 34 (2009) 6384-6392, http://dx.doi.org/10.1016/j.ijhydene. 2009.05.099.

[21] a. Sarvar-Amini, R. Sotudeh-Gharebagh, H. Bashiri, N. Mostoufi, a. Haghtalab, Sequential simulation of a fluidized bed membrane reactor for the steam methane reforming using ASPEN PLUS, Energy Fuels 21 (2007) 3593-3598, http://dx.doi. org/10.1021/ef7003514.

[22] A.M. Dehkordi, M. Memari, Compartment model for steam reforming of methane in a membrane-assisted bubbling fluidized-bed reactor, Int. J. Hydrogen Energy 34 (2009) 1275-1291, http://dx.doi.org/10.1016/j.ijhydene.2008.11.076.

[23] R. Jafari, R. Sotudeh-Gharebagh, N. Mostoufi, Modular simulation of fluidized bed reactors, Chem. Eng. Technol. 27 (2004) 123-129, http://dx.doi.org/10.1002/ceat. 200401908.

[24] F. Gallucci, M. Van Sint Annaland, J.a.M. Kuipers, Pure hydrogen production via autothermal reforming of ethanol in a fluidized bed membrane reactor: a simulation study, Int. J. Hydrogen Energy 35 (2010) 1659-1668, http://dx.doi.org/10.1016/j. ijhydene.2009.12.014.

[25] N.T.Y. Dang, F. Gallucci, M. van Sint Annaland, Micro-structured fluidized bed membrane reactors: solids circulation and densified zones distribution, Chem. Eng. J. 239 (2014) 42-52, http://dx.doi.org/10.1016/j.cej.2013.11.001.

[26] R. Porrazzo, G. White, R. Ocone, Fuel reactor modelling for chemical looping combustion: from micro-scale to macro-scale, Fuel 175 (2016) 87-98, http://dx. doi.org/10.1016/j.fuel.2016.01.041.

[27] A. Mahecha-Botero, Z. Chen, J.R. Grace, S.S.E.H. Elnashaie, C. Jim Lim, M. Rakib, et al., Comparison of fluidized bed flow regimes for steam methane reforming in membrane reactors: a simulation study, Chem. Eng. Sci. 64 (2009) 3598-3613, http://dx.doi.org/10.1016/j.ces.2009.04.044.

[28] J. Wang, L. Tan, M a. van der Hoef, M. van Sint Annaland, J.a.M. Kuipers, From bubbling to turbulent fluidization: advanced onset of regime transition in microfluidized beds, Chem. Eng. Sci. 66 (2011) 2001-2007, http://dx.doi.org/10.1016/j. ces.2011.02.003.

[29] A. Caravella, G. Barbieri, E. Drioli, Modelling and simulation of hydrogen permeation through supported Pd-alloy membranes with a multicomponent approach, Chem. Eng. Sci. 63 (2008) 2149-2160, http://dx.doi.org/10.1016/j.ces.2008.01. 009.

[30] T a. Peters, M. Stange, H. Klette, R. Bredesen, High pressure performance of thin Pd$23 \% \mathrm{Ag} /$ stainless steel composite membranes in water gas shift gas mixtures; influence of dilution, mass transfer and surface effects on the hydrogen flux, J. Membr. Sci. 316 (2008) 119-127, http://dx.doi.org/10.1016/j.memsci.2007.08. 056.

[31] E. Fernandez, A. Helmi, K. Coenen, J. Melendez, J.L. Viviente, D.A. Pacheco Tanaka, et al., Development of thin Pd-Ag supported membranes for fluidized bed membrane reactors including WGS related gases, Int. J. Hydrogen Energy 40 (2015) 3506-3519, http://dx.doi.org/10.1016/j.ijhydene.2014.08.074.

[32] A. Helmi, E. Fernandez, J. Melendez, D.A.P. Tanaka, F. Gallucci, M. Van Sint Annaland, Fluidized bed membrane reactors for ultra pure H2 production - A step forward towards commercialization, Molecules 2 (2016) 1, http://dx.doi.org/10 3390/molecules21030376.

[33] L. Trimm, Platinum-Alumina and of Methane on Fibre Catalysts-I, (1979).

[34] T. Numaguchi, K. Kikuchi, Intrinsic kinetics and design simulation in a complex reaction network; steam-methane reforming, Chem. Eng. Sci. 43 (1988) 2295-2301.

[35] C. Ruocco, E. Meloni, V. Palma, M. van Sint Annaland, V. Spallina, F. Gallucci, $\mathrm{Pt}-\mathrm{Ni}$ based catalyst for ethanol reforming in a fluidized bed membrane reactor, Int. J. Hydrogen Energy 41 (2016) 20122-20136, http://dx.doi.org/10.1016/j. ijhydene.2016.08.045.

[36] D. Pizzi, R. Worth, M. Giacinti Baschetti, G.C. Sarti, Kichi Noda, Hydrogen permeability of $2.5 \mu$ palladium-silver membranes deposited on ceramic supports, $\mathrm{J}$. Membr. Sci. 325 (2008) 446-453, http://dx.doi.org/10.1016/j.memsci.2008.08. 020 .

[37] E. Fernandez, K. Coenen, A. Helmi, J. Melendez, J. Zuñiga, D.A. Pacheco Tanaka, et al., Preparation and characterization of thin-film Pd-Ag supported membranes for high-temperature applications, Int. J. Hydrogen Energy 40 (2015) 13463-13478, http://dx.doi.org/10.1016/j.ijhydene.2015.08.050.

[38] S. Liguori, A. Iulianelli, F. Dalena, P. Pinacci, F. Drago, M. Broglia, et al., Performance and long-term stability of Pd/PSS and Pd/Al2O3 membranes for hydrogen separation, Membranes (Basel) 4 (2014) 143-162, http://dx.doi.org/10. 3390/membranes4010143.

[39] inopor n.d. http://www.inopor.com/en/products/membranes.html. (Accessed 31 July 2017). 